\title{
OBSTACLES OF ORGANIZATIONAL DEVELOPMENT - ANALYSIS OF OBSTACLES AND NECESSARY COMPETENCIES AND METHODS FOR SUCCESSFUL IMPLEMENTATION
}

\author{
Andrea Weigold ${ }^{1}$
}

\begin{abstract}
In order to keep up with the new requirements of a market or a business environment, organizational developments are a necessary change to align the company with the future. Every change in the company is associated with various obstacles, ranging from the difference between the current and the new business model to the employees' acceptance of the organizational development. In order to follow the new vision of the company, structured and extensive communication and structured planning of the implementation is required, in which every stakeholder has to be involved. The change that the organization implements must be accompanied by methods and models and thus learn in the development phase how to avoid obstacles and rejection to arouse motivation and interest so that uncertainties are prevented. Different methods are listed and evaluated in their implementation and content for a possibility for the change. The main focus is on the employees because without the acceptance of the most important stakeholders in a company, no further development is possible. If the employees do not support the vision, the change will fail. In order to accompany a successful development of the company, some necessary competencies and skills are listed, which are to be imparted by the company management and which the employee must acquire. This structured and modeled procedure is intended to accompany and enable change in a company.
\end{abstract}

JEL Classification Numbers: M1/M12/M54, DOI: https://doi.org/10.12955/peb.v2.266

Keywords: Organizational Development, Change Management, Analysis, Methods, Competencies.

\section{Introduction}

The business environment has changed dramatically in recent years, and digitization, the most radical change, has impacted all elements of value creation (Huber, 2018). The unprecedented information transparency is a new framework for even more intense competition (Kaune, 2010). This macroeconomic impact causes changes in the area of company size and employment (Niederberger, 2013). At this stage of the business, the improvement of business management is crucial to the future of an economic system (Wright, et al., 2013). Recognizing the reactions of people and becoming an observer of the people supports the accompaniment of changes that take place in the daily business with small steps in the center of organizations (Andreson, 2010). The employees are the objects that the manager of change must take care of (Doppler \& Lauterburg, 2019). This change manager is a new definition of management the coach or the consultant becomes a qualified service provider who accompanies the employees in the change (Doppler \& Lauterburg, 2019). These change managers select tools and instruments to be applied in different phases of the change. The change manager has to take care to choose tools that are adapted to the target group, and that reach the respective people with their context (Reis, 2012). The stakeholders in the company must support and accept the change process, it is about needs and moods, and it is about trust and information. Each individual involved must be fully informed about the change and prepared for their role in the process (Stolzenberg \& Heberle, 2013).

The goal must be a holistic concept that takes into account the employees, invalidates their resistance and consistently pursues the goals for the company (Kolb, 2008). Cooperation in a change process only succeeds if the employee trusts his entrepreneur and his manager. Through this basis of trust in themselves and others, the core of success is guaranteed (Heimsoeth, 2019). The executive must carry and exemplify this development and implementation of a model; this participation in the process and implementation is directly related to the success of the change (Seichter, 2003). By announcing a change and detailing the contents, there is no room for interpretation and erroneous assessments of individual situations. There is no stress in the ranks of the employees, and due to the conscious perception of the situation and the knowledge of the contents of the process, the evaluation and the perception of the change is more conscious and fear-free (Kostka, 2016).

All the mentioned processes of development, behaviors of the leaders and the company, and the confidence-building measures together with the leaders have the goal to satisfy the most important resource in the company, the employee, to ensure the company's functioning (Mening, 2014). The concept and model that can accompany a change in a company is the content of analysis and methods

\footnotetext{
${ }^{1}$ Comenius University Bratislava, Faculty of Mangement, Bratislava, Slovakia, Andrea.Weigold@partner.fressnapf.com
} 
that accompany an implementation in the form of a process (Kolb, 2008). Models and processes ensure that a situation no longer presents itself as a complex and confusing problem but removes the fear that this complexity and incompleteness are not obstacles (Dörner, 1995). No processes are blocked, no decisions are delayed, the transformation of the organization is implemented, and the change is not rejected (Brandes, 2005). The preconditions are, apart from the soft skills like, for example, the mentioned confidence. Also a first organization diagnosis, which illustrates a current state of the organization development and from this reason and with these data at a later time, conclusions to a change makes possible and for the examination of the reaching of the goal serves (Bornewasser, 2009). Other approaches to collaboration and re-organization of the company and knowledge sharing are the consideration of various redesign components such as:

- Job Design

- Team Design

- Communication methods

- Investment in technology

- Future-oriented leadership (Keyes, 2016)

Further methods and approaches to successfully lead employees and the company through organizational development, taking into account the obstacles and barriers, are explored in the following through a literature review.

\section{Obstacles to organizational development and barriers to implementation}

Change management presupposes different approaches and conditions in the enterprise, which are enumerated in the following and the basis for the further elaboration of the possible obstacles and resistances against the change. If not all approaches and conditions are fulfilled or at least observed; the change will not occur in the desired form or fail. The following conditions are considered the most important:

- Extensive communication

- Organizational Learning

- Increasing the willingness to change

- Involvement of all stakeholders (von der Lück, 2014)

The first obstacle to change in the company are organizational silos. If insights and knowledge are not exchanged, and valuable content is not shared across functions, only sub-areas in the company receive the information necessary for processes to function properly (Jones \& Reardo, 2013). The competencies remain reserved for a small circle of participants and prevent new ideas and methods from moving into the various departments or parts of the company.

This attitude on the part of management is associated with a lack of foresight and a lack of culture within the company. Culture can only enter a company, department and group if the organization itself represents a culture and if the management perceives the various stakeholders and values their personal contributions to the company's success (Walde, 2014). Valuing the individual stakeholders leads to pronounced trust among the people employed. Studies have shown that companies with a high level of trust-building measures and leadership styles weather crises better and that employees support and accept crisis-related changes and decisions in the company that are necessary and contribute to the good of the company (Herget \& Strobl, 2018). Sharing information and disseminating knowledge to all stakeholders who need the information create values and trust. Internal communication in the company is the most important task of a company. It can be observed that the difference between the desire for efficient internal communication and reality is large. (Montua, 2020). The task of internal company communication is to promote and decide the relationship with the employee:

- What content is provided

- How is the content provided

- Where is important content provided

- Which stakeholder receives which content (Bittner-Fesseler \& Häfelinger, 2018)

By providing knowledge, the qualification of employees increases and the expertise provided to him increases the competence of the individual. Building on each other is the knowledge, followed by the qualification, which are the essential prerequisites for competencies (Erpenbeck \&Sauter, 2015). The 
development of competencies requires a structured approach in the company. The planned objectives and the supplementary sub-objectives are to be provided with the necessary tasks. The tasks are to be assigned to the employees who can fulfill the tasks with their personal action competencies. In order to fulfill these tasks, the strategy of the company and the overriding goals must be known to the employees, as must the respective measures with which the company intends to achieve these goals (Hintz, 2018). Permanent and systematic training and further education of all employees in the company is essential for this approach. In today's world, where knowledge quickly becomes obsolete, it is necessary for employees to keep their know-how up to date. This is necessary to accompany the processes and the development of the organization because the employee understands and can evaluate the actions, procedure, and strategy (Schmeisser \& Claussen, 2009). The information that internal communication should provide is

- Inform

- Promote the dialogue

- Motivate

- Encourage the sharing of knowledge

- Lead (Montua, 2020)

In order to convey these contents, it is necessary to distinguish which communication flows take place in the company. These types of communication allow for variation and are therefore difficult to control, as opinions and content are communicated without sound knowledge, and a half-knowledge is created that deviates from the actual efficient communication (Hauenherm, 2018). The target-oriented type of communication is the one that does not allow any deviations and follows strict rules and guidelines. Every communication wants to achieve goals and is an action - actions without variation lead to desired results and do not allow assumptions that could cause a project or development to fail (Hauenherm, 2018).

Suppose the importance of communication is recognized in the company. In that case, a competence model is to be created, which makes the basics and the progress in the project visible with different contents adapted to the company. Like an evaluation table, the competence model contains the characteristics that a person in the company should provide as competence. Personal abilities, motivation, skills, behavior, interests are evaluated, and the results show where the employee can effectively contribute to the solution or which competencies need to be taught to the employee (Sonntag \& Schmidt-Rathjens, 2015). One approach is to create the competency model as a competency catalog. In the catalog, the most important competencies are detailed and assigned to the strategic objective. On one side are the objectives, which can be supplemented with existing competencies and thus the necessary qualification measures become clear. The goal is a complete profile that identifies job-relevant conclusions about all existing and non-existing competencies in the company (Thomaschewski \& Völker, 2019). The deepening of the competencies and comparing the existing competencies with the required competencies for the successful change can be analyzed more specifically and recorded in more detail with an internal stakeholder analysis. After competencies are known, important stakeholders in the company are identified. If the stakeholders are part of the change process, the interests are to be identified or inquired about, the possible resistances are to be derived from this, and special procedures are to be planned that can prevent these resistances (Vahs \& Weiland, 2020).

The interests of the stakeholders and their dependence on the company can be a result of the analysis, the development in the company of the individual stakeholders are important criteria for the stakeholder and the relationship to the organization are important statements for the change manager, these actions are all related to the company policy and allow important conclusions (Vahs \& Weiland, 2020). This internal information can be learned quickly and cost-effectively through an employee survey. The statements are valuable because they provide further content such as information about processes, profiles or weak points in the company (Sponheuer, 2010). Another team and organization diagnosis is the observation from the outside, by a company that is specialized in diagnoses and uses a supervisor for this procedure. He has no reservations, no previous experience, and as a process consultant, he can diagnose and point out development steps (Pelzmann \& Strümpf, 2018). The diagnosis is based on aspects such as the person and his role in the company, the communication, the structure and the processes with their effects on all participants. The goal of a diagnosis, the learning 
ability of the organization to promote, takes place after the holistic knowledge of the goals in the company and the identity of the employees with them, considers existing power dynamics and their influence on the goals as well as the culture that prevails in the company and has a great influence on the organization (Pelzmann \& Strümpf, 2018). If there is additional interest in the external impact of the company and the processes to customers and suppliers, a customer survey is recommended to identify opportunities for improvement and design processes effectively and efficiently (Kaminske, 2008). The use of mystery shoppers in undercover missions can also reveal weak points in the company, especially in direct customer contact, and thus offers the possibility of important sources of information (Reil, 2011). By diagnosing the company's processes, structures, and competencies, weak points can be uncovered and improvements and developments can be taken up with various measures. By identifying obstacles and rejections to change at an early stage, measures can be taken; some of these measures are discussed in the following chapter.

\section{Methods and measures to accompany and implement change processes}

The ideal type of every employee is "Puss in Boots" from the fairy tale of the same name. An initially narrow and insignificant inheritance in the form of a tomcat becomes the poor miller's main prize. Equipped with new boots, the cat goes out and wins new customers for the mill and the miller. $\mathrm{He}$ concentrates on the financially strongest customers and has the goal with high transactions to help the miller to liquidity and to a high market position. He was autonomous, creative and dynamic, intrinsically motivated, strategically thinking and independently pursuing entrepreneurial goals - the ideal employee (Wunderer, 2018). In order to position your own company successfully on the market and to offer all those involved the opportunity to make their knowledge and skills available to the organization and its development in a future-oriented manner, measures are necessary to enable everyone for this process. Those involved need to know and understand the company's goals and their own goals. Communication should be divided into three levels:

Strategic Level: Vision/Mission: Goal and Mission statement

Tactical Level: Implement Vision/Mission with business models, roadmaps as guidelines

Operational Level: the guideline sit implemented in the form of concrete plans, risk are identified and crises are prevented or managed in this way (Fink \& Siebe, 2016)

This mission and vision is followed by a possible process that provides the individual levels with actions and documents. Here, detailed courses of action are mentioned that accompany a successful change process.

Phase 1 Planning: strategy portfolio, resources, detailed plan of development

Phase 2 Execution: Assessment of the willingness of the participants, the constant communication of the current project status, development of new skills and behaviors and management of resistance

Phase 3 Follow-up: Ensuring implementation, control of target achievement, control of the program and completion of the process (Gallagher, 2019)

This structure and the accompanying measures make the process plausible, effective and goaloriented. The process becomes dynamic through the disclosure of all documented changes and extensive communication between the parties involved. By describing actual tasks and the principle of security in the process through freely accessible knowledge, areas of tension are avoided (Grote, 2004). The manager has the task of leading the participants and the employees in the style of employee orientation and participation orientation. Both orientations have to show appreciation for the employee and to put his concerns and needs in the foreground. The employee is involved in decision-making processes and viewed as a contributor (Franken, 2016). Developing employees into active and informed stakeholders has other benefits for the company. Employees make decisions consciously or unconsciously according to personal values. A distinction is made between qualitative values such as emotions, identity and the importance of work and quantitative values such as the functions of the individual in the company or financial benefits for work (Schaepfer \& Welz, 2017). These values are created in companies through the implementation of corporate culture. Culture is an orientation system for all participants and is also valid in society in groups and in organizations. Corporate culture must be lived and exemplified in all areas of the organization; it cannot be enforced. It reflects to all stakeholders the attitude towards employees, how they are treated, how mistakes are dealt with, and 
how people involved in the company deal with each other personally and socially (Genkova et al. 2013).

These stakeholders define this way of acting as belonging to society and the company. Since human needs for affiliation and orientation is central thinking, a feeling of insecurity is avoided for all participants the feeling of insecurity is avoided, and this need is fulfilled. If orientation and belonging are missing, the employee cannot develop a sense of right or wrong; he acts without meaning and without value, stress can result from this lack of orientation and massive disturbances can occur at all levels of the company (Genkova et al. 2013). Errors and disruptions in the company are associated as personal weakness or as unmotivated work. However, dealing openly with errors and the corporate culture required to do so leads to swift problem solving and faster processes in the company. In order to turn this error culture into a competitive company with functioning systems, all errors must be addressed and solutions must be found rationally and analytically (Hagen, 2017). The prerequisite for this is the corporate culture and the communicated objectives to all those involved in the company. The error is evaluated as a pure deviation from the target and can thus be assessed. If errors are dealt with openly and in a results-oriented manner, they can be regarded as success in a positive sense. Recognizing the deviations leads to corrections and improvements, which helps get closer to the solution and success (Mandl, 2017). This requires an application of various new methods, in recent research always called "Agile Management" or "Agile Methods". Hofer's (2016) definition of agility is the ability of teams and organizations to act flexibly, adaptively, and quickly in an uncertain, changing and dynamic environment. The teams become creative, empathetic, open, communicative, courageous and curious. Collaboration takes place in interdisciplinary teams, constantly connected and coordinated in each step and outcome (Triest \& Ahrend, 2019).

Breaking away from existing leadership habits and engaging with new leadership responsibilities requires an Agile way of working. The activities are delegated, and the leader takes a back seat, supports when needed, asks when he needs to know the current status of the project, or he perceives disruptive factors and observes the connections and the interfaces (Grote \& Goyk, 2018). The personal development of the leader is a prerequisite for agile leadership, the "new" leader covers the areas of culture in the company, structures and processes, can lead the team more effectively through distance and can effectively promote an agile implementation. (Sieroux, et al. 2020). Complexity in the work environment and increasingly higher and more extensive requirements make new and lean processes necessary (Häusling, 2014). The solution approach is planning in the organization with hierarchies that are as flat as possible, adapted to the company and to counteract the potential for conflict (Binckebanck et al. 2020). The employees organize themselves and complete tasks and projects on their own responsibility, the management responsibility is thus distributed to other roles and hierarchies are thus eliminated (Häusling, 2014). The manager can orientate himself on the strengths of the individual persons or participants and thus drive the development in the process and promote team development through the concrete use of competencies (Grote \& Goyk, 2018). All described applications of the all work method presupposes different basic conditions.

The use of agile methods alone does not make a company agile. The change in the company must be lived across all hierarchies and must include processes, methods, tools and a new understanding of leadership (Lang \& Wagner, 2019). Misunderstandings in connection with agile methods must also be avoided. Agility in the company does not mean immediate and new productivity, nor does it immediately create a great, new working atmosphere (Ehmann, 2019). Agile does not mean that everything is implemented and done immediately. Agile doesn't mean that employees can do everything the way they want to, and agile doesn't mean that it's just a short hype. Agile is not a selfrunner, it behaves the teams and the employees more flexible and faster to react and communicate better. You can't do a task without leadership, employees need to be directed and guided to focus and prioritize and not improvise and lose sight of the goal. As digitalization continues and the culture of working practices and collaboration continues to change and evolve, agile working will not be a hype but will accompany the culture of change in the business world for a long time (Ehmann, 2019) For the company, this means that formal and informal processes will continue to exist, organizational charts will also be needed for agile methods at every level of the organization, development within this leadership and hierarchy will become more customer-oriented, and individual self-organization will be strengthened (Sieroux et al. 2020). All projects require leadership, and agile and new methods must 
also be framed with clarified responsibilities, the right tool selection, project definition with analysis and design, and implementation (Prange, 2002). If, after the project has started, the employee or the team is led in self-responsibility, it must be ensured that the individual participants have the social competence, have the possibility to coordinate themselves and ensure that a defined goal can be achieved via the qualifications of the individual participants (Zollondz, et al. 2016). The goal control checks whether the set goal was reached, whether it was possible to reach it and is the measurement of the actual goal control in the deviation from the planned goal. In this form has the task of personnel development (Becker, 2011).

New working models with decentralized workplaces and with virtual workspaces are the new working worlds of the digital age, the original working time model of 9 to 5 will be history and replaced by tasks, challenges and projects (Hildebrandt \& Landhäuser, 2017). Technologies with virtual reality, voice-controlled assistance systems and artificial intelligence will improve and change the work culture (Fortmann \& Kolocek, 2018). The working world will experience new flexibility and will be able to complete multiple and more complex projects in a shorter time. The organization will become more economically successful in the long term. For this, they will need the freedom to work, confidence in themselves and their work, and facilitation to help and support them (Vigenshow, 2021). A facilitator can also be a mentor who accompanies the project as a role model and support. By mentoring another employee or team, it brings an experience and knowledge to the project without taking it over completely (Berthel \& Becker, 2017). A newcomer among the methods of organizational development is the method OKR-Objectives and Key Results. This new tool presupposes a fearless cooperation, allows mistakes and allows self-responsibility as far as possible (Kalkbrenner, 2020). The Key Results are the defined objectives, which must be measurable and verifiable, leaving no room for doubt. (Doerr, 2018). At the end of the defined period, whether the Key Result has been achieved or not must be verified.

The method of setting a goal, determining the period of time and checking the achievement of the goal after the period of time is simple to use. Due to the simple application, the method is highly effective and has many positive side effects (Kalkbrenner, 2020). The goals lead to clarity in each stakeholder's tasks. They lead to satisfaction through successes and structured work, with the possibility of making mistakes, and they show the priorities and guide the daily work through this focus (Doerr, 2018). The expertise of the stakeholders, their professional knowledge and the ability to solve both tasks and problems in a goal-oriented and methodical way, without losing sight of the goal and the task, help to fulfill the requirements and evaluate the result (Wilbers, 2014). Self-confidence of the person in himself and his work, the mindful and respectful interaction with other people, and moving appropriately in the social environment are important prerequisites for the necessary change process and the application of the new method (Kunkel, 2011).

\section{Conclusion}

The business world is changing, and it is subject to fluctuations, rapid changes and increased complexity. Nowadays, it is no longer "big eats small" but - fast eats slowly. You have to react quickly and competently to changes in the market and meet new framework conditions (Leopold, 2021). It takes foresight and the will to learn from the situation and to break new ground. In order to implement this necessary change in a company, the application of various methods is necessary. The implementation requires framework conditions such as extensive communication, the participation of all those concerned and the will to develop the organization through learning. Obstacles caused by the rejection of those involved because the meaning of the change is not recognized or because known and well-trodden paths have to be left, can be avoided through the active participation of people. Getting started in transition is the stock of the situation. Among other things, is to consider how the communication within the company runs and whether it can be improved to the necessary locations. The aim is to provide knowledge, at the positions where the knowledge is needed. In this context, the recipient of the message has to be checked. Is the right place staffed with the right person? Can this person transpose the obtained knowledge and the requirements targeted? How are mistakes handled in the company? An alternative for punishment when mistakes happen is one way to actively find them and reward the staff. This approach builds trust and supports the process to eliminate errors from the processes in the company. 
All methods and all scenarios assume that the employees support and endorse the approach. Possible reactions of employees, whether affective, normative or for costing, are described. A solution for a positive leadership is the use of godparents. A change is successful if the positions are filled with employees who actively support the change. The necessary control of the implementation can be diagnosed with different procedures. Examples are presented of some actions to make the success measurable. The skills that are needed to carry out these important steps in a company are among some in expertise, methodological competence and social competence. Without the ability to use these success-oriented skills, a change is difficult. Content of individual competencies are the necessary attitudes of the senior executive and the responsible employees. The competencies must be made available to the company and accessed from the employees, the employees must gain the security of being informed about the strategy, the vision and the goals of the company at all times and being able to work on these goals. The chosen method must be modern, fit the company and offer everyone the opportunity to implement it. Absolute openness in the process and the development of all those involved in the willingness to change and self-responsibility lead to the fact that all those involved gain confidence in the process and in the change and to accompany the change with all their possible strength. This procedure should reduce all obstacles and prejudices of those involved to a minimum and successfully shape the change process of a company so that the company will continue to operate successfully in the market in the future.

\section{References}

Albers, M. (2018) Digitale Erschöpfung [Digital exhaustion] in: Fortmann, H.R., Kolocek, B. [Editor] Arbeitswelt der Zukunft, Trends-Arbeitsraum-Menschen-Kompetenzen [Working world of the future, trends-workspace-peoplecompetences] 12

Anderson, D.L. (2010) Organizational Development: The process of Leading Organizational Change, 12

Becker, M. (2011) Systematische Personalentwicklung: Planung, Steuerung, Kontrolle im Funktionszyklus [Systematic personnel development: planning, management, control in the functional cycle] 279

Berthel, J., Becker, F.G. (2017) Personal Management: Grundzüge für Konzeptionen betrieblicher Personalarbeit [Personnel Management: Basic Features for Conceptions of Operational Personnel Work]

Binckebanck, L., Hölter, A.-K., Tiffert, A. [Editor] (2020) Führung von Vertriebsorganisationen: Strategie-KoordniationUmsetzung [Leading sales organizations: Strategy-Coordniation-Implementation]

Bittner-Fessler, A., Häfelinger, M. (2018) Kommunikation für junge Unternehmen, Das Praxishandbuch für Existenzgründer und Start-ups [Communication for young companies, The practical handbook for entrepreneurs and start-ups] $22 \mathrm{f}$

Bornewasser, M. (2009) Organisationsdiagnostik und Organisationsentwicklung [Organizational diagnostics and organizational development] 264

Brandes, D. (2005) Einfach Managen, Klarheit und Verzicht- der Weg zum Wesentlichen [Simply managing, clarity and renunciation- the way to the essentials] $62 \mathrm{ff}$

Doerr, J. (2018) OKR-Objectives \& Key Results: Wie Sie Ziele, auf die es wirklich ankommnt, entwickeln, messen und umsetzen

Doerr, J. (2018) OKR-Objectives \& Key Results: Wie Sie Ziele, auf die es wirklich ankommnt, entwickeln, messen und umsetzen [OKR-Objectives \& Key Results: How to develop, measure and implement goals that really matter]

Doppler, K., Lauterburg, C. (2019) Change Management: Den Unternehmenswandel gestalten [Change management: Shaping corporate change] 73

Dörner, D. (1995) Die Logik des Misslingens-Strategische Denken in komplexen Situationen [The Logic of Failure-Strategic Thinking in Complex Situations] 58

Ehmann, B. (2019) Quick Guide Agile Methoden für Personaler: So gelingt der Wandel in die agile Unternehmenskultur [Quick Guide Agile Methods for HR Managers: How to Successfully Make the Transition to an Agile Corporate Culture] 95

Ehmann, B. (2019) Quick Guide Agile Methoden für Personaler: So gelingt der Wandel in die agile Unternehmenskultur [Quick Guide Agile Methods for HR Managers: How to Successfully Make the Transition to an Agile Corporate Culture] 95

Erpenbeck J., Sauter, W. (2015) Wissen, Werte und Kompetenzen in der Mitarbeiterentwicklung: Ohne Gefühl geht in der Bildung gar nichts [Knowledge, values and competencies in employee development: Nothing works in education without feeling] $1 \mathrm{ff}$

Fink, A., Siebe, A. (2016) Szenario Management: Von strategischem Vorausdenken zu zukunftsrobusten Entscheidungen [Scenario Management: From Strategic Forward Thinking to Future Robust Decisions] 35

Franken, S. (2016) Führen in der Arbeitswelt der Zukunft: Instrumente, Techniken und Best-Practice-Beispiele [Leading in the working world of the future: tools, techniques and best practice examples] $31 \mathrm{f}$

Gallagher, P.F. (2019) a2B Change Management Pocket Guide: The leadership of Change vol. 2, 3

Genkova, P., Rengeisen, T., Leong, F.T.L. [Editor] Handbuch Stress und Kultur: Interkulturelle und Kulturvergleichende Perspektiven [Handbook Stress and Culture: Intercultural and Comparative Cultural Perspectives] $41 \mathrm{f}$ 
Genkova, P., Rengeisen, T., Leong, F.T.L. [Editor] Handbuch Stress und Kultur: Interkulturelle und Kulturvergleichende Perspektiven [Handbook Stress and Culture: Intercultural and Comparative Cultural Perspectives] $41 \mathrm{f}$

Grote, G., Schuler, H. [Editor], Sonntag, K. [Editor](2007) Handbuch der Arbeits- und Organisationspsychologie [Handbook of Industrial and Organizational Psychology] 157

Grote, S., Goyk, R. [Editor] (2018) Agile Führung-das neue Gutwort im Management [Agile leadership-the new buzzword in management] in:Führungsinstrumente aus dem Silicon Valley, Konzepte und Kompetenzen [Leadership tools from Silicon Valley, concepts and competencies] 31

Grote, S., Goyk, R. [Editor] (2018) Agile Führung-das neue Gutwort im Management, in:Führungsinstrumente aus dem Silicon Valley, Konzepte und Kompetenzen [Agile Führung-das neue Gutwort im Management, in:Führungsinstrumente aus dem Silicon Valley, Konzepte und Kompetenzen] 31

Hagen, J.U. (2017) Fatale Fehler, oder warum Organisationen ein Fehlermanagement brauchen [Fatal errors, or why organizations need error management] $6 f$

Hauenherm, E. (2018) Effiziente Kommuniaktion im Unternehmen: Konzepte und Lösungen mit Microsoft Plattformen [Efficient communication in the enterprise: Concepts and solutions with Microsoft platforms]

Hauenherm, E. (2018) Effiziente Kommuniaktion im Unternehmen: Konzepte und Lösungen mit Microsoft Plattformen [Efficient communication in the enterprise: Concepts and solutions with Microsoft platforms]

Häusling, A. (2014) https://sigs-datacom.de/uploads/tx-dmjournlas/Hauesling-os-Agility-14.pdf

Häusling, A. (2014) https://sigs-datacom.de/uploads/tx-dmjournlas/Hauesling-os-Agility-14.pdf

Heimsoeth, A. (2019) Vertrauen entscheidet: Die vergessene Basis der Führung [Trust is decisive: The forgotten basis of leadership] 7

Herget, J., Strobl, H. [Editor] (2018) Unternehmenskultur in der Praxis: Grundlagen-Methoden-Best Practice [Corporate Culture in Practice: Basics-Methods-Best Practice] 50

Hildebrandt, A., Landhäuser, W. (2017) CSR und Digitalisierung, Der digitale Wandel als Chance und Herausforderung für Wirtschaft und Gesellschaft [CSR and digitalization, The digital transformation as an opportunity and challenge for business and society] 52

Hintz, A. (2018) Erfolgreiche Mitarbeiterführung durch soziale Kompetenz: Eine praxisbezogene Anleitung [Successful people management through people skills: a practical guide] 77

Huber, W. (2018) Industrie 4.0 kompakt-Wie Technologien unsere Wirtschaft und unsere Unternehmen verändern, [Industry 4.0 compact-How technologies are changing our economy and our companies] 107

Jones, D.J., Reardo, R.J. (2013) Leading and Implementing Business Change Management: Making Change Stick in the contemporary Organization, 23

Kalkbrenner, C. (2020) Business Reinventing mit OKR, So entkommen Sie dem Sog der Krise [Business Reinventing with OKR, How to escape the maelstrom of the crisis] 54

Kaune, A. (2010) Change Management mit Organisationsentwicklung, [Change management with organizational development] 15

Keyes, J. (2016) Enterprise 2.0: Social Networking, Tools to Transform Your Organization, 257

Kolb, M. (2008) Prozessmanagement: Grundlagen-Konzepte-Praxis [Process Management: Fundamentals-ConceptsPractice] 431

Kostka, C. (2016) Change Mangement: Das Praxishandbuch für Führungskräfte [Change Management: The Practical Handbook for Managers]

Kunkel, K. (2011) Sozialkompetenz- ein Manager Märchen? [Social competence- a manager fairy tale?] $37 \mathrm{ff}$

Lang, M. [Editor], Wagner, R. (2019) Der Weg zum projektorientierten Unternehmen- Wissen für Entscheider [The way to a project-oriented company- knowledge for decision makers]

Leopold, M.J. (2021) OKR Strategieentwicklung und Umsetzung in einem agilen Umfeld, Einführung in das Framework zur Strategieumsetzung im 21. Jahrhundert [OKR Strategy development and implementation in an agile environment, introduction to the framework for strategy implementation in the 21st century] 11

Leopold, M.J. (2021) OKR Strategieentwicklung und Umsetzung in einem agilen Umfeld, Einführung in das Framework zur Strategieumsetzung im 21. Jahrhundert[OKR Strategy development and implementation in an agile environment, introduction to the framework for strategy implementation in the 21st century] 25

Montua, A. (2020) Führungsaufgabe Interne Kommunikation, Erfolgreich im Unternehmen kommunizieren- im Alltag und in Veränderungsprozesse [Leadership Task Internal Communication, Communicating Successfully in the Company - in Everyday Life and in Change Processes] 7

Montua, A. (2020) Führungsaufgabe Interne Kommunikation, Erfolgreich im Unternehmen kommunizieren- im Alltag und in Veränderungsprozesse [Leadership Task Internal Communication, Communicating Successfully in the Company - in Everyday Life and in Change Processes] 8

Niederberger, D.-U. (2013) Handelsbetriebe als Teil der Volkswirtschaft, [Trading companies as part of the national economy] 41

Pelzmann, S., Strümpf, B. (2018) Integrative tools für die Team- und Organisationsdiagnose: Wirksam beraten [Integrative tools for team and organizational diagnosis: effective consulting] 26 
Prange, C. (2002) Organisationales Lernen und Wissensmanagment [Organizational learning and knowledge management] 203

Reil, H. (2011) Mystery Shopping: Testkäufe sind in geheimer Mission Servie-Sündern auf der Spur [Mystery shopping: test purchases are on the trail of servie offenders on a secret mission] Genios Wirtschaftswissen 05/2011

Reis, M. (2012) Change Management: A Balanced and Blended Approach, 75

Seichter, M. (2003) Möglichkeiten und Grenzen der Organisationsentwicklung zum Change Management [Possibilities and limits of organizational development for change management] 9

Schaepfer, K., Wlez, M. (2017) Das dynamische Unternehmen: Wie Wertewandel, Innovation und Digitalisierung zum Erfolg führen [The dynamic company: How value change, innovation and digitalization lead to success]

Schmeisser, W., Claussen, L. (2009) Controlling und Berliner Balanced Scorecard [Controlling and Berliner Balanced Scorecard] 102

Sieroux, S., Roock, S., Wolf, H. (2020) Agiles Leadership: Führungsmodelle, Führrungsstile und das richtige Handwerkszeug für die agile Arbeitswelt [Agile leadership: leadership models, leadership styles and the right tools for the agile world of work] 9

Sieroux, S., Roock, S., Wolf, H. (2020) Agiles Leadership: Führungsmodelle, Führrungsstile und das richtige Handwerkszeug für die agile Arbeitswelt [Agile leadership: leadership models, leadership styles and the right tools for the agile world of work] 9

Sonntag, K., Schmidt-Rathjes, C. (2015) Anforderungsanalyse und Kompetenzmodelle [Requirements analysis and competence models] in: Gonon, P., Klauser, F., Nickolaus, R., Huisinga, R. [Editor] Kompetenz, Kognition und Neue Konzepte der beruflichen Bildung [Competence, Cognition and New Concepts of Vocational Training] 55

Sponheuer, B. (2010) Employer Branding als Bestandartikel einer ganzheitlichen Markenführung [Employer branding as a component of holistic brand management] 166

Stolzenberg, K., Heberle, K. (2013) Change Management: Veränderungsprozesse erfolgreich gestalten-Mitarbeiter mobilisieren [Change Management: Successfully Shaping Change Processes-Mobilizing Employees] $5 \mathrm{f}$

Triest, S., Ahrend, J. (2019) Agile Führung: Mitarbeiter und Teams erfolgreich führen und Coachen [Agile Leadership: Successfully Leading and Coaching Employees and Teams]

Vahs, D., Weiland, A. (2020) Workbook Change Management: Methoden und Techniken [Workbook Change Management: Methods and Techniques]

Vahs, D., Weiland, A. (2020) Workbook Change Management: Methoden und Techniken [Workbook Change Management: Methods and Techniques]

Vigenschow, U. (2021) Lernende Organistaionen: Das Management komplexer Aufgaben und Strukturen [Learning Organistaions: The management of complex tasks and structures]

Walde, A. (2014) Von der Organisationsentwicklung zum Change Management [From organizational development to change management] 51

Wilbers, K. (2014) Wirtschaftsunterricht gestalten [Design business lessons] 70

Wright, M. [Editor] Siegel, D.S., Keasey, K., Filatotchev, J. (2013) The Oxford Handbook of Corporate Governance, 48 Wunderer, R. (2018) Führung und Zusammenarbeit in Märchen und Arbeitswelten [Leadership and collaboration in fairy tales and working world] $6 \mathrm{f}$

Zollondz, H.D., Ketting, M., Pfundtner, R. [Editor] (2016) Lexikon Qualitätsmanagement, Handbuch des modernen Managements auf Basis des Qualitätsmanagements [Quality management encyclopedia, handbook of modern management based on quality management] 424 